\title{
Luteal peptides and their genes as important markers of ovarian differentiation
}

\author{
R. Ivell, R. Bathgate and N. Walther \\ Institute for Hormone and Fertility Research, University of Hamburg, Grandweg 64, \\ 22529 Hamburg, Germany
}

\begin{abstract}
Secreted peptide hormones and components of the steroidogenic machinery are molecules that are expressed usually in high amounts and in a time- and cell-specific fashion within the cells that give rise to the bovine corpus luteum. They thus serve as useful markers for the events occurring within the nuclei of these cells that result in differentiation and the expression of the specific luteal phenotype. We have studied the bovine genes of three such luteal products: oxytocin, the new relaxin-like factor (RLF), and the steroidogenic acute regulatory protein (StAR). The oxytocin gene is expressed in the granulosal cells of the preovulatory follicle and in the large luteal cells of the immediately resulting early corpus luteum. The RLF gene is a major thecal cell product in antral and atretic follicles. It is also transcribed in luteal cells, but only in the mid- to late ovarian cycle and in pregnancy, following a temporal pattern of expression very similar to that of relaxin in pigs. The StAR gene appears to be upregulated only in the mid- to late ovarian cycle, several days after the increase in steroidogenic enzymes associated with luteinization and progesterone production. All three genes make use of the transcription factor SF-1 (Ad4BP) and, although they all respond to LH activation of adenylate cyclase, none utilize CRE-linked systems. Specific transcriptional activation must involve other factors to encode the information for the widely diverse temporal and cellular patterns of gene expression for these three genes.
\end{abstract}

\section{Introduction}

The bovine derivatives of the mesonephric mesenchymal cells of the embryonic female gonad offer an ideal model system in which to investigate differentiation processes in a steroidogenic tissue. In a synchronous fashion through the course of embryonic and postnatal development, and then later in each ovarian cycle and in pregnancy, these cells exhibit a marked switching on and off of genes, which are important for the changing phenotype of the ovary. We have been especially interested in the major switching systems involved in luteinization, that is the differentiation of cells of the membrana granulosa and theca interna of the preovulatory follicle into a functional corpus luteum, and in luteal maintenance in the event of pregnancy. In order to access the molecular systems involved in such gene-switching events one makes use of genes that encode molecules central for the specifically changing phenotype of the ovary. In the case of the bovine model, suitable genes are those for components of the steroidogenic pathway, and those encoding secreted peptide hormones. The reason for their usefulness is that they show a high degree of temporal and cell-type specificity, are expressed synchronously in the granulosal, thecal or luteal cells, are expressed in high amounts (often up to $1 \%$ of all transcripts), and their expression can be studied in a regulated fashion at different levels (mRNA, protein, function) in primary cell cultures. Although a large number of genes fall into this category, our studies have focussed on three genes representing different cell or temporal specificity. In this way, we have been able to dissect some of the molecular mechanisms occurring in the cell nuclei involved in the formation of a healthy corpus luteum from a preovulatory follicle. These are the genes for the secreted peptide hormones oxytocin and the new 
relaxin-like factor (RLF), and for the intracellular signalling peptide StAR (steroidogenic acute regulatory peptide).

\section{Oxytocin}

The production of oxytocin by the ruminant corpus luteum has been described by a number of authors (for example Flint and Sheldrick, 1982; Wathes and Swann, 1982; Fields et al., 1983; Ivell and Richter, 1984; Ivell et al., 1985, 1990; Meidan et al., 1992; Fortune and Voss, 1993). The important features of oxytocin biosynthesis are first that the nonapeptide hormone is made as part of a larger precursor polypeptide, together with neurophysin I. Thus post-translational processing, particularly within the Golgi and dense-core secretory vesicles, must form an important part of any regulatory pathway, as also the regulated release of those granules by specific secretagogues, such as prostaglandin $(\mathrm{PG}) \mathrm{F}_{2 \mathrm{ig}}$. Second, ruminants express much more oxytocin in the ovary than do nonruminant species. Whereas in the latter (for example primates), the function of oxytocin is thought to be paracrine within the ovary, in ruminants oxytocin forms part of an endocrine positive feedback loop involving oxytocin receptors on the epithelium of the uterine endometrium; upon stimulation of these receptors at oestrus large amounts of $\mathrm{PGF}_{2 \alpha}$ are released which in the absence of pregnancy lead to luteolysis and further secretion of luteal oxytocin. From the point of view of gene regulation, in the cow oxytocin mRNA is exclusively produced within the luteinizing granulosal cells of the preovulatory follicle and in the large luteal cells of the early corpus luteum (Fehr et al., 1987). The oxytocin gene is upregulated only in highly oestrogenic follicles following the LH surge (Holtorf et al., 1989), and appears to be downregulated 3-5 days after ovulation (Fig. 1; Ivell et al., 1985; Fehr et al., 1987). Only very small amounts of oxytocin mRNA can be detected in the corpus luteum of pregnancy, although an upregulation of the oxytocin gene appears to occur again in the luteal cells of the corpus luteum after the onset of labour at term of pregnancy (Ivell et al., 1995). Thus, the bovine oxytocin gene can act as an indicator gene for regulatory events occurring at these times and in the granulosa-large luteal cell lineage.

There have been numerous studies on oxytocin secretion and gene expression in primary cell cultures. Earlier studies using luteal cells showed that, in general, any oxytocin detected was being secreted from premade stores, and that under most conditions the oxytocin gene was permanently downregulated in such cell cultures (McArdle and Holtorf, 1989; Furuya et al., 1990). Granulosal cells derived from large preovulatory follicles with high oestrogen concentration in the follicular fluid have yielded most information on regulation of the oxytocin gene. These cells appear to luteinize spontaneously in culture, producing high concentrations of progesterone. However, whereas the presence of serum has little effect on steroidogenesis, it appears to be quite inhibitory for the production of oxytocin. For optimal induction of the oxytocin gene, less than $1 \%$ fetal calf serum is necessary, together with either insulin or insulin-like growth factor I (IGF-I), acting via independent receptors (Holtorf et al., 1989). At submaximal concentrations of insulin or IGF-I (for example $10-100 \mathrm{ng} \mathrm{ml}^{-1}$ ), further addition of either LH or FSH to stimulate adenylate cyclase leads to a further increase of gene expression. However, at higher insulin or IGF-I concentrations, activation of adenylate cyclase by these hormones has little further influence. In the absence of insulin or IGF-I, no amount of LH or FSH can induce oxytocin gene expression. Recently, we have been able to show that an essential part of the upregulation of the oxytocin gene at luteinization involves a local positive feedback loop comprising the luteal steroid progesterone (Lioutas et al., 1997). Addition of the competing antigestagens RU486 or onapristone to insulin/forskolin-stimulated bovine granulosal cells completely inhibited the transcription of the oxytocin gene and consequently the production of the peptide hormone (Lioutas et al., 1997). However, oestrogens have no effect on oxytocin production by cultured granulosa-luteal cells (Furuya et al., 1990; McArdle et al., 1991).

The switching on and off of genes is a complex resultant of a number of different processes, beginning with local changes in chromatin structure, the activation of the DNA by single or combined transcription factors and cofactors, and finally by inhibition or reversal of these processes. We have studied the bovine oxytocin gene extensively in the context of its activation in luteinizing 


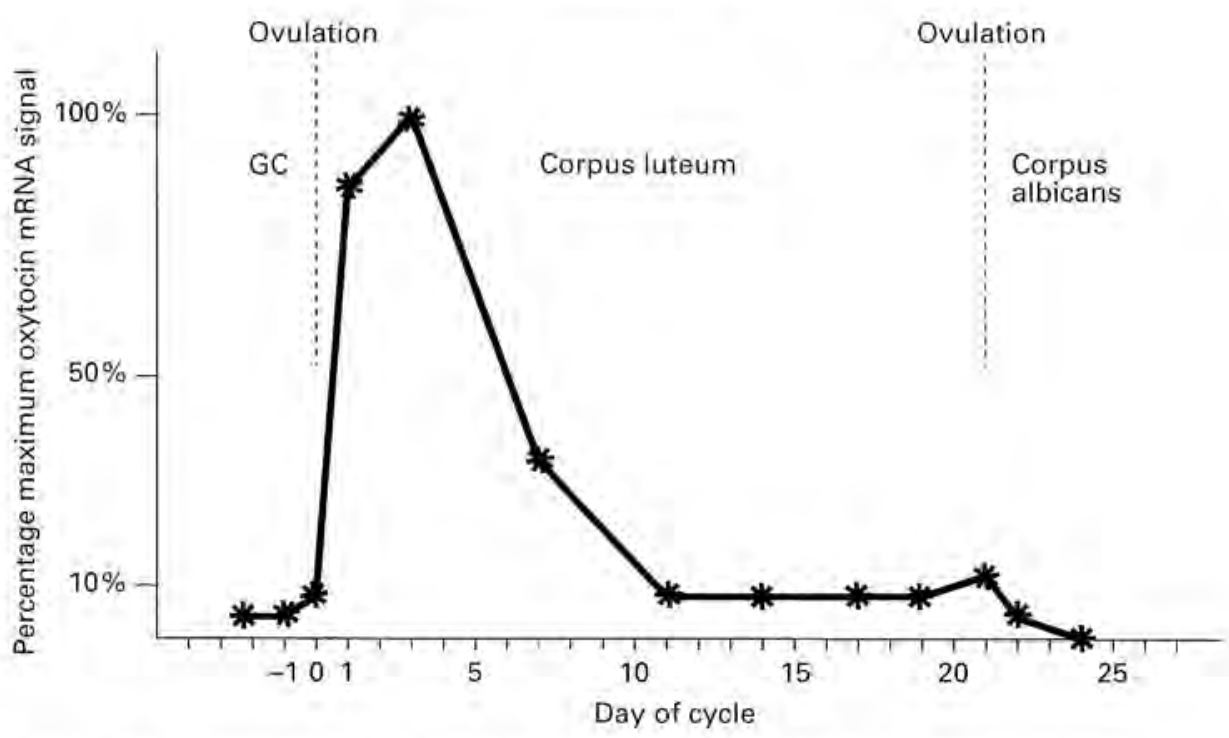

Fig. 1. Specific oxytocin-mRNA levels in the bovine corpus luteum of the oestrous cycle (GC, freshly prepared granulosal cells). $10 \mathrm{mg}$ of total RNA from bovine corpora lutea collected at the times indicated were subjected to dot blot hybridization to a bovine oxytocin-gene-specific probe radiolabelled using ${ }^{32} \mathrm{P}$. This was followed by autoradiography and densitometric estimation of the resulting specific signals, which were expressed as percentage of the maximum signal measured. Redrawn from Ivell et al. (1985).

bovine granulosal cells. An investigation of the in vivo pattern of methylation in the upstream promoter region of the gene indicated regions that are specifically hypomethylated when the gene is being actively transcribed (Kascheike et al., 1997). As might be expected, there is hypomethylation in the proximal region of the transcription start site up to about $-500 \mathrm{bp}$; however, this does not appear to be absolutely tissue specific. The second hypomethylated region is further upstream in the distal promoter at -1700 to $-1900 \mathrm{bp}$ (Fig. 2). This hypomethylation appears to be specific to luteinizing granulosal cells actively transcribing the oxytocin gene. Although several studies using human and rat oxytocin gene promoter-reporter constructs in heterologous transfections have suggested that different members of the steroid receptor superfamily (for example ER $\alpha$, TR, RAR $\alpha$ ) can interact with the oxytocin gene promoter under these artificial conditions, we have been able to show that for active transcription of the bovine oxytocin gene in luteinizing granulosal cells, only the orphan receptor SF-1 binds within this proximal promoter region (Wehrenberg et al., 1994a, b). SF-1 appears to be replaced by another related factor, COUP-TF, when the gene is being downregulated in the mid-cycle corpus luteum (Wehrenberg et al., 1992, 1994a). Using protein factors extracted from bovine cells and tissues wherein the oxytocin gene is endogenously up-or downregulated, we have further been able to show that in the distal region of the promoter, there is first binding of lutealspecific nuclear factors to two artiodactyl-specific repeat regions (Fig. 2; Walther et al., 1991). Second, our results indicate that another novel transcription factor, which is similar though not identical to SF-1, also binds in the distal promoter (about -1800 bp; Kascheike et al., 1997), a region which, as noted above, appears to be specifically hypomethylated in tissues in which the gene is actively transcribed. Although the oxytocin gene is expressed only in follicles containing high oestrogen, there is no evidence to date for an interaction of a nuclear oestrogen receptor with the oxytocin gene promoter, nor is there any evidence for an interaction with the progesterone receptor. This is surprising in view of the marked inhibition of oxytocin gene transcription in luteinizing granulosal cells by antigestagens (Lioutas et al., 1997). 


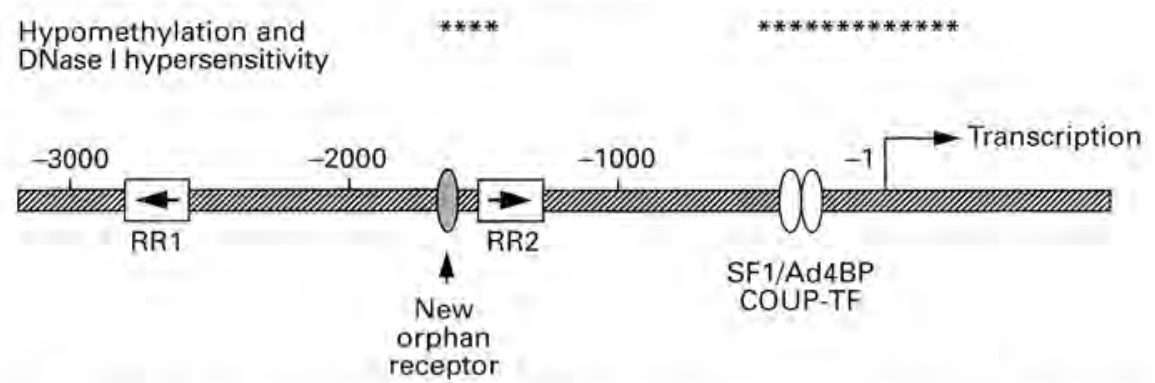

Fig. 2. Schematic representation of the bovine oxytocin gene promoter indicating the locations of luteal-specific nuclear factor binding and sites of specific genomic hypomethylation and in vivo DNaseI hypersensitivity $\left({ }^{* *}\right)$, both implying regions of open chromatin. RR1 and RR2 (artiodactyl-specific repeat sequences; Walther et al., 1991). For further details, see text and Kascheike et al. (1997).

Together, these data imply that genetic information within the first 2000 upstream nucleotides of the transcription start site is sufficient to regulate oxytocin gene expression. However, attempts to express the bovine oxytocin gene transgenically in mice using comparable promoter-reporter constructs have led to curious results. When a short promoter including the region -1 to -500 is used, there is no ovarian expression, nor expression in the hypothalamus, where high levels of expression would be expected. However, there is substantial expression of the transgene specifically in the Sertoli cells of the mouse testis (Ang et al., 1991, 1994). Longer promoter regions failed to yield significant expression. However, when a part of the genetically linked bovine vasopressin gene is included in a mini-locus construct, specific hypothalamic expression is detected, although there is still no expression in the ovary of these transgenic mice (Ang et al., 1993). When the bovine vasopressin gene promoter is used to drive the transgene, there is expression in the ovary (Ho et al., 1995), although this gene is not expressed under normal conditions in the ovary of the cow. These unexpected results would imply that probably there are interactions between nuclear factors and the promoters of both the vasopressin and oxytocin genes, which lie very close together (about $8 \mathrm{~kb}$ apart) within the bovine genome, before one of these genes is expressed in specific cell types.

\section{Relaxin-like Factor}

It is well known that there is a relaxin-type of physiology associated with parturition in cows (Anderson et al., 1995). Furthermore, application of porcine relaxin can induce cervical dilatation in cows, just as in species such as the pig and the rat (Anderson et al., 1995). However, all attempts to characterize a bovine relaxin at the molecular level have failed (Hartung et al., 1995a), and in the sheep it has been shown that there is a large deletion in the relaxin genomic locus (Roche et al., 1993). A novel member of the relaxin-insulin-IGF family of genes was identified as being expressed exclusively in the testicular Leydig cells of pigs, humans, rats, mice, sheep and bulls (reviewed in Ivell, 1997). The cloned cDNAs from these species encoded a molecule with a very similar B-C-A peptide domain structure to that of relaxin, including a motif in the B-domain which shows high similarity to the proposed receptor-binding motif in relaxin. Indeed, a chemically synthesized peptide was shown to bind to mouse relaxin receptors (Büllesbach and Schwabe, 1995). For this reason the new gene product, originally referred to as Leydig-insulin-like peptide (Adham et al., 1993), is now more generally referred to as relaxin-like factor (RLF). Having cloned the RLF cDNA from the bovine testis (Bathgate et al., 1996), we were able to show that in cows, unlike in all nonruminant species, the RLF gene is expressed at a very high level also in the ovary. In situ hybridization analysis showed that it was expressed exclusively in the theca interna of antral follicles, but also of atretic follicles, as well as in the corpus luteum (Bathgate et al., 1996). A more 


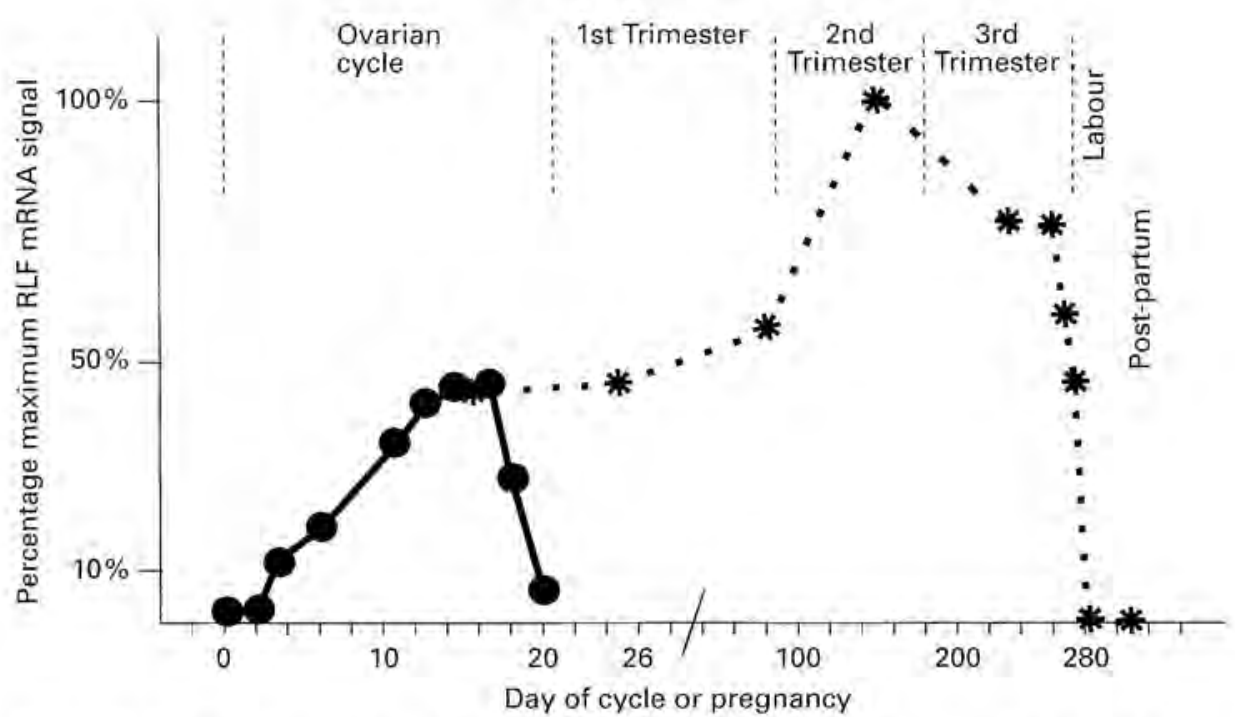

Fig. 3. RLF-mRNA profile in the bovine corpus luteum through the oestrous cycle (solid line) and pregnancy (dashed line). Briefly northern blot hybridizations were performed with $10 \mathrm{mg}$ total RNA extracted from bovine corpora lutea at the times indicated; these were hybridized to a bovine RLF-specific ${ }^{32} \mathrm{P}$-labelled CDNA probe, and the resulting signals measured using a phosphorimager. Data derived from R. Bathgate, M. Fields and R. Ivell (unpublished).

detailed analysis of expression in the corpus luteum was obtained using northern blots of luteal RNA from various times of the cycle and pregnancy (summarized in Fig. 3; Bathgate, Fields and Ivell, unpublished). Although it is expressed highly in the theca interna of the preovulatory follicle, it is evidently downregulated upon ovulation. Within the corpus luteum there is only low expression in the early cycle; however, the RLF gene is evidently upregulated in the mid-late luteal phase in what appear to be the large luteal cells (Fig. 4). In the event of pregnancy the maximum values of the cycle are maintained and even increased reaching a maximum at the end of the second trimester. Amounts of RLF mRNA fall markedly at term, and transcripts are undetectable during labour. This pattern of gene expression is very similar to that reported for the related hormone relaxin in the pig ovary, and supports the notion that in the cow, RLF might be substituting for the missing relaxin. To date it has not been possible to purify the endogenous RLF peptide so that physiological experiments to confirm this idea cannot yet be performed. We have succeeded in raising antibodies against peptide fragments as well as bacterially produced human and mouse RLF. These antibodies appear to work well in an immunohistochemical context (Ivell et al., 1997; Balvers et $a I_{,}$, 1998); however, except for one of these (Fig, 4), they fail to work in the cow. Neither do they appear to function in the context of western blots or immunoassays. It is clearly of great importance to produce better antibodies so that a study of this very interesting molecule can be pursued at protein and functional levels.

Given the high endogenous RLF gene expression in the thecal cells of bovine antral follicles, we have begun to study the regulation of this expression using primary thecal cell cultures. Preliminary experiments show that in all culture conditions the RLF gene is initially downregulated with a kinetic which varies somewhat under different experimental conditions. Of great interest, however, is the observation that under continuous IGF-I or insulin stimulation, RLF mRNA increases again after about 6 days in culture, maintaining a high level for several days (Bathgate, Moniac and Ivell, unpublished). Addition of fetal calf serum appears to irrevocably downregulate the RLF gene. Thus, the reappearance of RLF mRNA upon insulin or IGF-I stimulation appears to follow a time course in cell culture, which is parallel to the upregulation of RLF in the corpus luteum in vivo. 

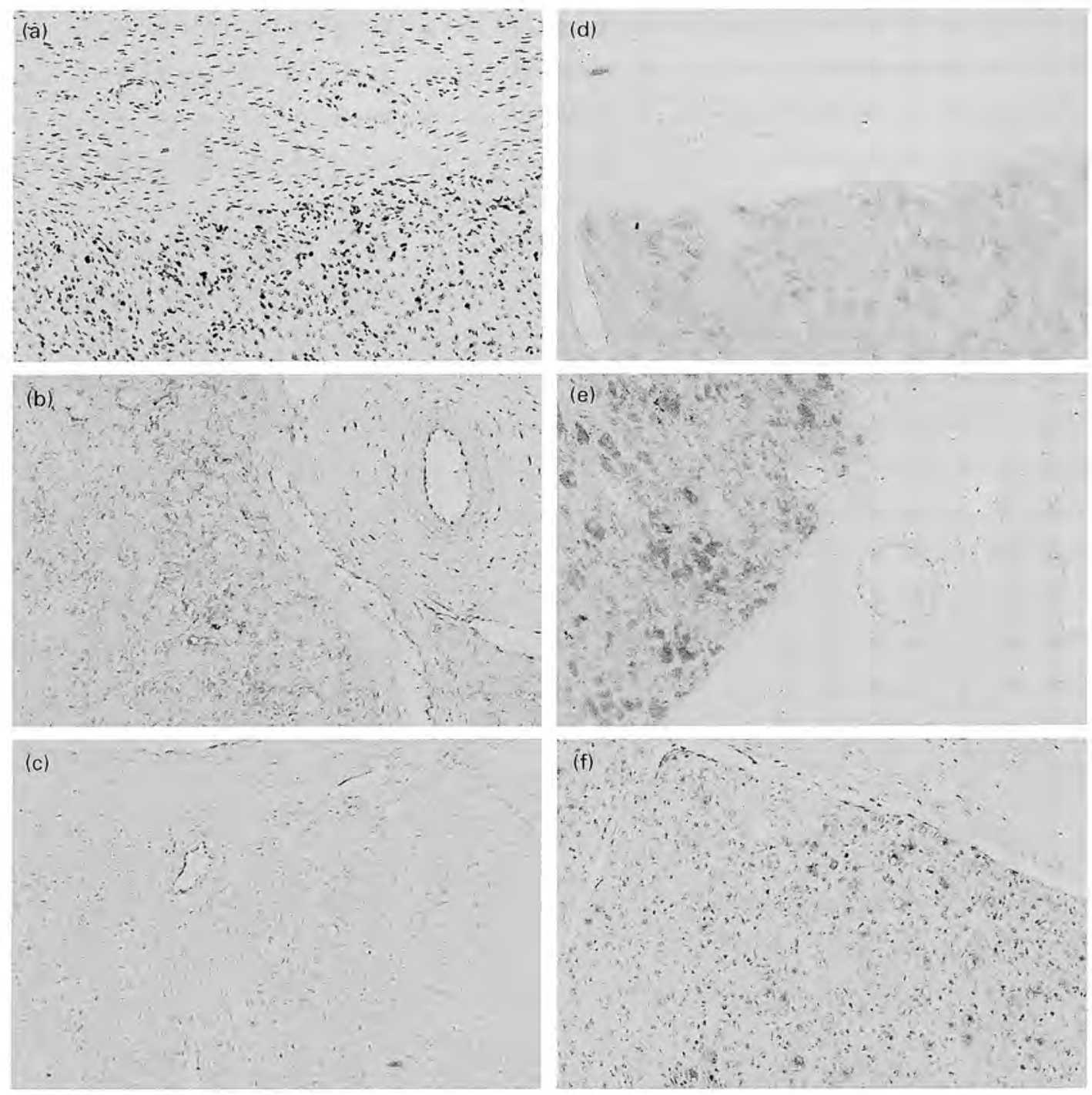

Fig. 4. Immunohistochemical staining for bovine relaxin-like factor (RLF) in the corpus luteum of the oestrous cycle. (a)-(c) Controls replacing the primary antibodies by preimmune serum from the same animals. (d)-(f), as (a)-(c), anti-RLF antiserum M1 (Ivell et al., 1997). The antibody M1 was raised against a peptide epitope of the RLF B-domain which is identical in human and bovine RLF sequences. (d) Early-mid-cycle; (e) mid-late cycle; (f) late cycle (day 21). Conditions for immunohistochemistry were as in Ivell et al. (1997)

The bovine RLF gene has not yet been studied. However, there is some information already on the gene for mouse RLF (Zimmerman et al., 1997; Koskimies et al., 1997). In this species, in which RLF is highly expressed in the testis, and expressed at a very low level only in the ovary (Balvers et al., 1998), it appears that only a few hundred nucleotides of the promoter region upstream of the transcription start site are sufficient to confer a degree of cell specificity, as well as high activity in promoter-reporter transfection experiments (Koskimies et al., 1997). This region includes two recognition motifs for the transcription factor SF-1. An interesting feature of the mouse RLF gene, 


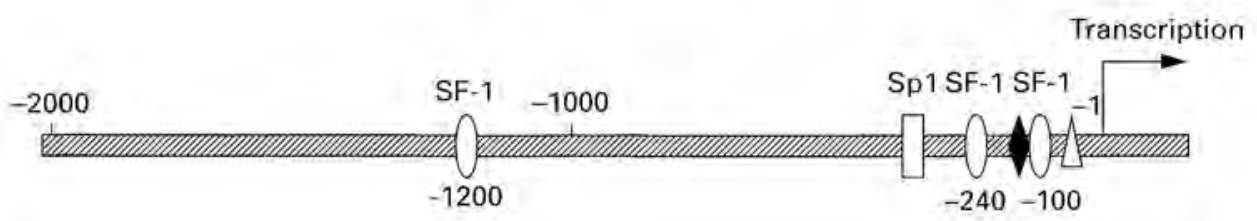

Fig. 5. Schematic representation of the bovine StAR gene promoter indicating the locations of the putative binding motifs for SF-1 (Ad4BP; ellipses), DAX-1 (triangle), C/EBP 3 (filled rhombus), Sp1 (rectangle), See Rust et al. (1998) for further details.

which appears to be true also for the human RLF gene (Safford et al., 1997), is that it appears to be wholly included within an intron of a quite different gene, namely that for the signal transduction molecule JAK3 (Koskimies et al., 1997).

\section{Steroidogenic Acute Regulatory Protein}

The steroidogenic acute regulatory (StAR) peptide is a small intracellular protein, which is considered to be responsible for the acute regulation of steroidogenesis in the testis, ovary and adrenal gland (reviewed in Stocco, 1998). It functions by interacting with the mitochondrion and, presumably, via the transient establishment of contact points between the outer and the inner mitochondrial membrane, allows the transfer of cholesterol to the steroidogenic enzyme complex on the inner mitochondrial surface. As part of a differential cloning project to identify genes expressed in the bovine corpus luteum of the late ovarian cycle and pregnancy, we were able to clone the full-length bovine StAR transcript for the longer of the two mRNA species evident in northern hybridizations (Hartung et al., 1995b; Pescador et al., 1996). The difference in size of the two commonly seen transcripts lies in a differential polyadenylation (Hartung et al., 1995b). The steady state levels of StAR mRNA in the bovine corpus luteum indicate that these basal levels begin to increase only in the mid- to late cycle, as has recently also been shown in pigs (LaVoie et al., 1997), and remain high throughout pregnancy. This result is somewhat confusing, since the initial upregulation occurs about 5 days after the upregulation of P450scc mRNA and the increase in progesterone production. Thus, if the StAR peptide is involved in acute regulation of steroidogenesis also in the bovine ovary, this is evidently not reflected by the basal levels of the specific transcript. However, from preliminary studies assessing StAR gene expression in bovine adrenal cells (Nicol et al., 1997), as well as in gonadotrophin-stimulated rat ovaries (Ronen-Fuhrmann et al., 1998), it would appear that there is a rapid transient increase in StAR mRNA upon activation of adenylate cyclase by $\mathrm{ACTH}$ or $\mathrm{LH}$, respectively.

We have recently succeeded in cloning the complete genomic sequence of the bovine StAR gene, including approximately $3 \mathrm{~kb}$ of the $5^{\prime}$ promoter region upstream of the transcription start site (Rust et al., 1998). Computer analysis identified three motifs in this region corresponding to the SF-1 (Ad4BP) transcription factor binding site (Fig. 5). Use of heterologous transfection systems, whereby a bovine SF-1 expression vector was co-transfected into the cells together with appropriate bovine StAR promoter-deletion reporter constructs, indicated that the two proximal SF-1 motifs at -100 and -240 interacted with SF-1 to induce an upregulation of the gene. Furthermore, additional cotransfection of a constitutive protein kinase A catalytic subunit indicated that the effect of cAMP was probably mediated by SF-1. However, upon performing electrophoretic mobility shift assays to detect specific DNA-nuclear protein binding, it was found that bovine SF-1 is incapable of binding to the most proximal $(-100)$ motif, and only very weakly to the second $(-240)$ site. Instead SF-1 showed excellent binding to the most distal $(-1000)$ motif. This discrepancy between the two types of experiment suggests that in vivo the SF-1 mediated regulation of the bovine StAR gene is probably more complex and may involve a number of additional cofactors or interactions with other as yet 
unidentified transcription factors (Rust et al, 1998). Computer analysis has identified putative motifs also for the single-strand DNA-binding DAX-1, for SpI, and for C/EBPB (Fig. 5), although whether these can be utilized either in vitro or in vivo has yet to be demonstrated.

\section{The role of SF-1 (Ad4BP) in Follicular/Luteal Cell Differentiation}

At present there are three different genes that are expressed in different cell types and at different times within the differentiation pathway of the bovine corpus luteum. The oxytocin gene is expressed in granulosa-lutein cells of the early cycle; the RLF gene is expressed in theca-lutein cells of the follicle and in the corpus luteum of the late cycle and pregnancy; the StAR gene is probably expressed at a low basal level in unstimulated granulosal and thecal cells of the follicle, but at increased basal levels only in the corpus luteum of the mid- to late cycle and in pregnancy. However, whereas the upregulation in vitro of the oxytocin gene requires stimulation for about $16 \mathrm{~h}$ of adenylate cyclase activation before an increase is evident, the StAR gene - at least in bovine adrenal cells - increases already after only $1 \mathrm{~h}$. The RLF gene in contrast appears to be upregulated in the corpus luteum first after 4-6 days of stimulation.

All of these genes include motifs for the transcription factor SF-1 (Ad4BP) in their 5' promoter regions. Equally, although they exhibit a pattern of expression in vivo which would correlate with adenylate cyclase activation (either by $\mathrm{LH}$ or by $\mathrm{PGF}_{2 \mathrm{a}}$ ), none includes the classic response element for such activation which could interact with the CREB or related transcription factors. These genes thus differ from the bovine inhibin- $\alpha$ gene which is upregulated in granulosa-lutein cells via the mediation of a typical CRE motif (Ungefroren et al., 1994). The bovine oxytocin, RLF and StAR genes are thus also like the genes for some of the steroidogenic enzymes (for example CYP11A and CYP21B; Lauber et al., 1993) which also include an important SF-1 motif, are regulated by adenylate cyclase activation, but in a CRE-independent fashion (Lauber et al. 1993). The conclusion that must be drawn from all these studies is that while SF-1 is an essential permissive factor targetting gene expression to the cells of the mesonephric mesenchymal lineage, and possibly also directly mediating some of the activating information from the cAMP-linked second messenger system, it is only one component in a complicated transcriptional regulatory complex. There must be further components that discriminate between granulosal and thecal cell-specific expression, and which determine the timing of luteal gene expression. Such dynamic features probably involve not simply activating molecules but probably are the resultants of complex interactions between activating and inactivating cofactors. It has recently been shown that SF-1 mediated gene transcription can be activated by the interaction of SF-1 with the transcription factor WT-1 (Nachtigal et al,, 1998). In contrast, SF-1 may interact with the factor DAX-1 to recruit the inactivating cofactor complex which includes the $\mathrm{N}$-CoR protein (Crawford et al., 1998). We have shown for the bovine oxytocin gene that binding of SF-1 can be inhibited by competitive binding of another related factor, COUP-TE, to the same cis element (Wehrenberg et al., 1994a,b). It has also been suggested for the StAR gene in the rat testis (Zazopoulos et al, 1997) that SF-1 interaction can be sterically blocked by a DNA-dependent binding of DAX-1 to a single-strand region of a hairpin loop in the immediate neighbourhood of one of the proximal SF-1 cis elements. It has also been shown that there may be a synergistic activating interaction between SF-1 and other DNA-dependent transcription factors, such as C/EBP (Nalbant et al., 1998). Thus there is probably a wide variety of different molecular mechanisms which acting through the mediation of SF-1 can lead to the type of coded response needed to explain the highly specific expression patterns of luteal genes.

\section{Conclusion}

We are probably only just beginning to unravel the complexity of the molecular codes responsible for specific gene expression in the cells of the granulosa-theca-luteal lineages. In this context, the study of hormone genes, and in particular those involved in the production of luteal peptides as well 
as steroids, together with the power of the bovine ovarian system, should help us to reach a better understanding of ovarian function and its pathology.

\section{Appendix: List of Abbreviations}

Transcription factors are indicated in the text by their common acronyms: C/EBP $\beta$, CCAAT/ enhancer-binding protein $\beta$; COUP-TF, chicken ovalbumin upstream promoter-transcription factor; CREB, CAMP-responsive element (CRE) binding protein; CREM, CRE-modulator protein; DAX-1, dosage-sensitive sex-reversal, $X$-linked gene; ER $\alpha$ and ER $\beta$, oestrogen receptor $\alpha$ and $\beta ; P R$, progesterone receptor; $R A R$, retinoic acid receptor; SpI, Simian virus 40 specific transcription factor 1; TR, thyroid hormone receptor.

The authors are very grateful to all the members of the Hamburg team, who over the years have helped us to unravel some of the complexity of luteal gene expression. They would particularly like to thank Ms Nicole Moniac for allowing us to refer to some of her unpublished data. They also thank the Deutsche Forschungsgemeinschaft for continued financial support of this project (Iv7/1 and Iv7/5).

\section{References}

Adham IM, Burkhardt E, Benahmed M and Engel W (1993) Cloning of a cDNA coding for a novel insulin-like peptide of the testicular Leydig cells Journal of Biological Chemistry $26826668-26672$

Anderson LL, Gazal OS, Dlamini B and Li Y (1995) The role of relaxin in ruminants. In Progress in Relaxin Research pp 428-438 Eds AH McLennan, G Tregear and G BryantGreenwood. World Scientific Publishing, Singapore

Ang HL, Ungefroren $\mathrm{H}$, De Bree E, Foo NC, Carter D, Burbach JPH, Ivell R and Murphy D (1991) Testicular oxytocin gene expression in seminiferous tubules of cattle and transgenic mice Endocrinology 128 2110-2117

Ang HI, Carter DA and Murphy D (1993) Neuronspecific expression and physiological regulation of bovine vasopressin transgenes in mice EMBO joumal 12 $2397-2409$

Ang HL, Ivell R, Walther N, Nicholson $\mathrm{H}$, Ungefroren $\mathrm{H}$, Millar M, Carter D and Murphy D (1994) Over-expression of oxytocin in the testes of a transgenic mouse model Joumal of Endocrinology 140 53-62

Balvers $M$, Spiess AN, Domagalski R, Hunt $N$, Kilic E, Mukhopadhyay A, Hanks E, Charlton HM and Ivell R (1998) Relaxin-like factor expression as a marker of differentiation in the mouse testis and ovary Endocrinology 139 2960-2970

Bathgate R, Balvers Mr Hunt N and Ivell R (1996) Relaxin-like factor gene is highly expressed in the bovine ovary of the cycle and pregnancy: sequence and messenger ribonucleic acid analysis Biology of Reproduction 55 1452-1457

Büllesbach E and Schwabe C (1995) A novel Leydig cell-derived protein is a relaxin-like factor Journal of Biological Chemistry 270 16011-16015

Crawford PA, Dorn C, Sadovsky Y and Milbrandt J (1998) Nuclear receptor Dax-1 recruits nuclear corepressor $\mathrm{N}$-CoR to Steroidogenic Factor 1 Molecular and Cellutar Biology 18 2949-2956

Fehr S, Ivell R, Koll R, Schams D, Fields M and Richter D (1987) Expression of the oxytocin gene in the large cells of the bovine corpus luteum FEBS Letters 210 45-50

Fields PA, Eldridge RK, Fuchs AR, Roberts RF and Fields M] (1983) Human placental and bovine corpora luteal oxytocin Endocrinology 112 1544-1546
Flint APF and Sheldrick EL (1982) Ovarian secretion of oxytocin is stimulated by prostaglandin Nature 297 587-588

Fortune JE and Voss AK (1993) Oxytocin gene expression and action in bovine preovulatory follicles Regulatory Peptides $45257-261$

Furuya K, McArdle CA and Ivell R (1990) The regulation of oxytocin gene expression in early bovine luteal cells Molecular and Cellular Endocrinology 70 81-88

Hartung S, Kondo S, Abend N, Hunt N, Rust W, Balvers M, BryantGreenwood G and Ivell R (1995a) The search for ruminant relaxin. In Progress in Relaxin Research pp 439-456 Eds AH McLennan, G Tregear and G Bryant-Greenwood. World Scientific Publishing, Singapore

Hartung S, Rust W, Balvers M and Ivell R (1995b) Molecular cloning and in vioo expression of the bovine steroidogenic acute regulatory protein Biochemical and Bioplysical Research Communications 215 646-653

Ho MY, Carter DA, Ang HI and Murphy D (1995) Bovine oxy tocin transgenes in mice: hypothalamic expression, physiological regulation and interactions with the vasopressin gene Journal of Biological Chemistry 270 27199-27205

Holtorf AP, Furuya K, Ivell R and McArdle CA (1989) Oxytocin production and oxytocin messenger ribonucleic acid levels in bovine granulosa cells are regulated by insulin and insulin-like growth factor-l: dependence on developmental status of the ovarian follicle Endocrinology $1252612-2620$

Ivell R (1997) Biology of the relaxin-like factor (RLF) Reviews of Reproduction 2 133-138

Ivell R and Richter D (1984) The gene for the hypothalarnic peptide hormone oxytocin is highly expressed in the bovine corpus luteum: biosynthesis, structure and sequence analysis EMBO foursal $32351-2354$

Ivell R, Brackett KH, Fields MJ and Richter D (1985) Ovulation triggers oxytocin gene expression in the bovine ovary FEBS Letfers 190 263-267

Ivell R, Hunt N, Abend N, Brackmann B, Nollmeyer D, Lamsa JC and McCracken JA (1990) Structure and ovarian expression of the oxytocin gene in sheep Reproduction Ferfility and Development 2 703-711

Ivell R, Rust W, Einspanier A, Hartung S, Fields $M$ and Fuchs AR (1995) Oxytocin and oxytocin receptor gene expression in 
the reproductive tract of the pregnant cow: rescue of luteal oxytocin production at term Biology of Reproduction $\mathbf{5 3}$ 553-560

Ivell $\mathrm{R}$, Balvers $\mathrm{M}$, Domagalski $\mathrm{R}$, Ungefroren $\mathrm{H}$, Hunt $\mathrm{N}$ and Schulze W (1997) Relaxin-like factor: a highly specific and constitutive new marker for Leydig cells in the human testis Molecular Human Reproduction 3 459-466

Kascheike B, Ivell R and Walther N (1997) Alterations in the chromatin structure of the distal promoter region of the bovine oxytocin gene correlate with ovarian expression DNA and Cell Biology 16 1237-1248

Koskimies P, Spiess AN, Lahti P, Huhtaniemi I and Jvell R (1997) The mouse relaxin-like factor gene and its promoter are located within the $3^{\prime}$ region of the JAK3 genomic sequence FEBS Lefters 419 186-190

Lauber ME, Kagawa N, Waterman MR and Simpson ER (1993) cAMP-dependent and tissue-specific expression of genes encoding steroidogenic enzymes in bovine luteal and granulosa cells in primary culture Molecular and Cellular Endocrinology 93 227-233

LaVoie HA, Benoit AM, Garmey JC, Dailey RA, Wright DJ and Veldhuis JD (1997) Coordinate developmental expression of genes regulating sterol economy and cholesterol sidechain cleavage in the porcine ovary Biology of Reproduction 57 402-407

Lioutas C, Einspanier A, Kascheike B, Walther N and Ivell R (1997) An autocrine progesterone positive feedback loop mediates oxytocin upregulation in bovine granulosa cells during luteinization Endocrimology 138 5059-5062

McArdle CA and Holtorf AP (1989) Oxytocin and progesterone release from bovine corpus luteum cells in culture: effects of insulin-like growth factor $\mathrm{I}$, insulin and prostaglandins Endocrinology 124 1278-1286

McArdle CA, Kohl C, Rieger K, Gröner I and Wehrenberg U (1991) Effects of gonadotrophins, insulin and insulin-like growth factor 1 on ovarian oxytocin and progesterone production Molecular and Cellular Endocrinology 78 211-220)

Meidan R, Altstein M and Girsh E (1992) Biosynthesis and release of oxytocin by granulosa cells derived from preovulatory bovine follicles: effects of forskolin and insulin-like growth factor-I Biology of Reproducfion 46 $715-720$

Nachtigal MW, Hirokawa X, Enyeart-VanHouten DL, Flanagan JN, Hammer GD and Ingraham HA (1998) Wilms' tumor 1 and Dax-1 modulate the orphan nuclear receptor SF-1 in sexspecific gene expression Cell $93445-454$

Nalbant D, Williams SC, Stocco DM and Khan SA (1998) Luteinizing hormone-dependent gene regulation in Leydig cells may be mediated by CCAAT/enhancerbinding protein- $\beta$ Endocrinology 139 272-279

Nicol MR, Morley SD, Stirling D, Ivell R, Walker SW and Mason II (1997) The expression of steroidogenic acute regulatory protein (StAR) mRNA in bovine adrenocortical cells Iournal of Endocrinology 152 (Supplement) P7

Pescador N, Soumano $\mathrm{K}$, Stocco DM, Price CA and Murphy BD
(1996) Steroidogenic acute regulatory protein in bovine corpora lutea Biology of Reproduction 55 485-491

Roche PJ, Crawford RJ and Tregear GW (1993) A single copy relaxin-like gene sequence is present in sheep Molecular and Cellular Endocrinólogy 91 21-28

Ronan-Fuhumann T, Timberg R, King SR, Hales KH, Hales DB, Stocco DM and Orly J (1998) Spatio-temporal expression patterns of steroidogenic acute regulatory protein (StAR) during follicular development in the rat ovary Endocrinology 139 303-315

Rust W, Stedronsky K, Tillmann G, Morley S, Walther $\mathrm{N}$ and Ivell R (1998) The role of SF-1/Ad4BP in the control of the bovine gene for the Steroidogenic Acute Regulatory (StAR) protein Journal of Molecular Endocrinology 21 189-200

Safford MG, Levenstein M, Tsifrina E, Amin S, Hawkins AL, Griffin CA, Civin CI and Small D (1997) JAK3: expression and mapping to chromosome $19 \mathrm{p} 12-13.1$ Experimental Hematology 25 374-386

Stocco D (1998) A review of the characteristics of the protein required for acute regulation of steroid hormone biosynthesis: the case for the steroidogenic acute regulatory (StAR) protein Proceedings of the Society for Experimenlal Biology and Medicine 217 123-129

Ungefroren H, Wathes DC, Walther N and Ivell R (1994) Structure of the alpha-inhibin gene and its regulation in the ruminant gonad: inverse relationship to oxytocin gene expression Biology of Reproduction $50401-412$

Walther N, Wehrenberg U, Brackmann B and Ivell R (1991) Mapping of the oxytocin gene control region: identification of binding sites for luteal nuclear proteins in the $5^{\prime}$ noncoding region of the gene Journal of Neuroendocrinology 3 539-549

Wathes DC and Swann RW (1982) is oxytocin an ovarian hormone? Nature 297 225-227

Wehrenberg U, Ivell $\mathrm{R}$ and WaIther $\mathrm{N}$ (1992) The COuP transcription factor (COUP-TF) is directly involved in the regulation of oxytocin gene expression in luteinizing bovine granulosa cells Biophysical and Biochemical Research Communications 189 496-503

Wehrenberg U, Ivell $\mathrm{R}$, Jansen $\mathrm{M}$, Von Goedecke S and Walther $\mathrm{N}$ (1994a) Two orphan receptors binding to a common site are involved in the regulation of the oxytocin gene in the bovine ovary Procedings of the National Academy of Sciences USA 91 1440-1444

Wehrenberg U, Von Goeddecke S, IvelI R and Walther N (1994b) The orphan receptor $\mathrm{SF}-1$ binds to the COUP-like element in the promoter of the actively transcribed oxytocin gene Journal of Neuroendocrinology 6 1-4

Zazopoulos E, Lalli E, Stocco DM and Sassone-Corsi P (1997) DNA-binding and transeriptional repression by DAX-1 blocks steroidogenesis Nature $390 \quad 311-315$

Zimmermann S, Schöttler P and Adham I (1997) Mouse Leydig insulin-like (Ley-I-L) gene structure and expression during testis and ovary development Molecular Reproduction and Development $4730-38$ 